\title{
Characterization of $\beta$-Nerve Growth Factor-TrkA system in male reproductive tract of rabbit and the relationship between $\beta$-NGF and testosterone levels with seminal quality during sexual maturation
}

\author{
Ana Sanchez-Rodriguez a , Maria Arias-Alvarez ${ }^{\mathrm{b}}$, Patricia Timón a , José M. Bautista ${ }^{\mathrm{c}}$, \\ Pilar G. Rebollar ${ }^{\text {, }}$, Pedro L. Lorenzo ${ }^{\text {a }}$, Rosa M. Garcia-Garcia ${ }^{\text {a, * }}$, \\ a Department of Physiology, Faculty of Veterinary Sciences, Complutense University of Madrid, Madrid, Spain \\ ${ }^{\mathrm{b}}$ Department of Animal Production, Faculty of Veterinary Sciences, Complutense University of Madrid, Madrid, Spain \\ ${ }^{\mathrm{c}}$ Department of Biochemistry and Molecular Biology, Faculty of Veterinary Sciences, Complutense University of Madrid, Madrid, Spain \\ d Department of Agrarian Production, ETSIAAB, Polytechnic University of Madrid, Madrid, Spain
}

\section{A R T I C L E I N F O}

\section{Article history:}

Received 6 July 2018

Received in revised form

3 December 2018

Accepted 4 December 2018

Available online 10 December 2018

\section{Keywords:}

$\beta$-NGF

TrkA receptor

Seminal plasma

Sex organs

Testosterone levels

Male rabbits

\begin{abstract}
A B S T R A C T
$\beta$-Nerve Growth Factor ( $\beta$-NGF) is a neurotrophin which acts through its receptors TrkA and p75, performing important actions in male reproductive physiology and its presence in seminal plasma (SP) has been related to male fertility. The aim of the present study was to evaluate the gene expression profile and the immunolocalization of $\beta$-NGF and its high-affinity receptor TrkA in sex organs in rabbits during sexual maturation period. $\beta$-NGF concentration for both SP and blood plasma (BP) and BP testosterone levels were determined as well as the seminal parameters during such period. Ten New Zealand White $\mathrm{x}$ California young rabbits were trained to semen collection since 20 weeks of age and routinely done once a week with two ejaculations per session. At 22 and 37 weeks of age, semen collection was carried out three times a week and seminal parameters were evaluated. Four males were randomly assigned and slaughtered in each age $(n=8)$; sex organs (prostate, bulbourethral glands and epididymis) were dissected and collected to determine $\beta$-NGF and TrkA gene expression and immunolocalization. SP and $\mathrm{BP}$ were also taken at each semen collection session to evaluate $\beta$-NGF concentration, and testosterone levels were also assessed in BP. The highest $\beta$-NGF mRNA expression was observed in prostate compared to bulbourethral glands and epididymis. These two last tissues showed residual $\beta$-NGF mRNA expression and limited localization of the neurotrophin. The prostate epithelial cells and lumen were strongly stained with regard to the other sex organs indicating that immunolocalization of $\beta$-NGF rely mainly in the prostate. TrkA gene expression was lower but constant and differentially immunolocalized in the sex organ tissues. Finally, $\beta$-NGF concentration in SP and BP remained unchanged in accordance to age, while some seminal characteristics such as sperm concentration, percentage of live sperm and mass and progressive motility were enhanced as endowed by BP testosterone variation. $\beta$-NGF and its cognate TrkA receptor are expressed and immunolocalized in the male reproductive tract in the two ages studied, independently of the circulating levels of testosterone and $\beta$-NGF.
\end{abstract}

(๐) 2018 Elsevier Inc. All rights reserved.

\section{Introduction}

$\beta$-Nerve Growth Factor ( $\beta$-NGF) is a neurotrophic factor essential for survival, development and maintenance of sympathetic and sensory neurons of the peripheral nervous system [1]. Its biological

\footnotetext{
* Corresponding author. Dept. Physiology, Faculty of Veterinary Science, Complutense University of Madrid, Avda. Puerta de Hierro s/n, 28042, Madrid, Spain.

E-mail address: rosa.garcia@vet.ucm.es (R.M. Garcia-Garcia).
}

function is mediated by two receptors: a specific high-affinity transmembrane receptor, named TrkA, and a low-affinity and non-selective receptor member of the death-promoting Tumor Necrosis Factor family, called p75. $\beta-\mathrm{NGF} / \mathrm{TrkA} / \mathrm{p} 75$ system is present in numerous organs apart from the nervous system, such as the reproductive tract both in males [2-10] and females [11-14], where has been demonstrated to have relevant physiological functions. Thus, $\beta$-NGF and its receptors have been associated with the morphological sex determination, testis morphogenesis and 
development, and sperm maturation [15-19], suggesting the involvement of $\beta$-NGF system in the reproductive tract maturation. In addition, it is hypothesized that $\beta$-NGF may intervene in spermatogenesis process by mediating the effects of testosterone [19]. This fact has been studied in some species but the regulation of $\beta$ NGF/TrkA system by androgens [20] or vice versa [21] is unclear. In this respect, the characterization of this system in the reproductive tract during sexual maturity and the relationship with sexual hormones could be interesting to determine its function in this process.

$\beta$-NGF has been found in the seminal plasma (SP) $[9,10,22-26]$, which is a mixture of secretions from testes, epididymis and male accessory glands [27]. Proteins present in SP have been demonstrated to perform important functions in protection, sperm transport, capacitation and motility of sperm within the female reproductive tract $[28,29]$. In this way, $\beta$-NGF expression levels in bovine sperm had positive influence on some sperm velocity parameters, which suggest an important role of $\beta$-NGF on fertility [30]. In addition, this neurotrophin in SP has been revealed as an ovulation trigger factor in induced ovulating species, such as camelids [22-25]. In rabbits, despite being reflex ovulators, neither rabbit SP $[24,31]$ nor murine $\beta-\mathrm{NGF}[10]$ have been able to provoke the ovulation, thus the role of $\beta$-NGF as an ovulation-inducing factor is still inconclusive. Nonetheless, a recent study in this species proposes that this neurotrophin participates in ovulation induction by both endocrine and nervous pathways [32] with some unrevealed function/s in the female reproduction.

In male rabbits, $\beta$-NGF were detected in testes, prostate and seminal vesicles $[2,9,10]$. Although we have recently described the gene expression and distribution of low-affinity receptor p75 in epididymis and bulbourethral glands in rabbits [33], the characterization of $\beta$-NGF and its specific receptor TrkA in some male reproductive organs remains unknown. To the best of our knowledge, there are no evidences of their presence in epididymis in rabbits, whereas it is described in other mammals [5,15], and there is only one work which studies $\beta$-NGF by radioimmunoassay in bulbourethral glands [2]. Nothing is known about their expression and distribution during sexual maturity in males or their correlation to seminal characteristics and testosterone levels.

Therefore, in the present study, to further understanding of the role of $\beta$-NGF/TrkA system in male rabbit reproduction, we examined the distribution and gene expression of $\beta$-NGF and its highaffinity receptor (TrkA) in prostate, bulbourethral glands and epididymis during the sexual maturation period. In addition, we investigated the variation of $\beta$-NGF expression in SP in relation to $\beta$ NGF and testosterone levels in blood plasma (BP) and SP, as well as their relationship with seminal parameters to determine whether the protein levels could be related with semen viability and motility.

\section{Material and methods}

\subsection{Experimental design}

Ten New Zealand White $\mathrm{x}$ California young rabbits were used for this experiment. The experimental design was completely random with two groups ( 22 and 37 weeks old); the experimental unit was one buck. The experiment started when males were 20 weeks old. From this time until the end of the experiment ( 37 weeks old) semen was collected by artificial vagina once a week with two ejaculations per session to keep bucks sexually active. The interval between first and second ejaculate was $15-20 \mathrm{~min}$. When bucks reached 22 weeks old, four of them were sacrificed and sex organs were recovered for real time PCR and immunohistochemistry studies. The six remaining rabbits were maintained until the end of the experiment (37 weeks old), where four were sacrificied for tissue recovery. The two remaining rabbits were kept in the farm as breeding males. $\beta$-NGF in SP and BP and testosterone BP levels were determined in these rabbits at 22 and 37 weeks old. For sperm analyses, semen collection was performed three times a week with two ejaculations per session at the same ages. For each male in one session, first and second ejaculate were mixed to determine semen quality and to separate SP.

All the procedures were performed in accordance with the policies of the University Scientific Ethics Spanish Policy for Animal Protection RD53/2013 [34], which meets the European Union Directive about the protection of animals used in experimentation.

\subsection{Housing and feeding}

Male rabbits (Oryctolagus cuniculus) were held on the experimental farm at the Agrarian Production Department, Polytechnic University of Madrid (UPM, Spain). They were housed in individual cages $(700 \mathrm{~mm} \times 500 \mathrm{~mm} \times 320 \mathrm{~mm}$ ) under controlled conditions of constant photoperiod (16L:8D), 20 to $25^{\circ} \mathrm{C}$ of temperature and a relative humidity of $60-75 \%$ maintained by a forced ventilation system. Each animal had free access to food and water.

\subsection{Collection and evaluation of seminal samples}

The semen samples recovered at 22 and 37 weeks of age were analyzed as follow. After semen collection, the gel fraction was removed and the ejaculates were kept warmed in an incubator at $37^{\circ} \mathrm{C}$ after being macroscopically analyzed, taking into account their color, their volume (assessed by a graduated plastic pipette) and the presence of sedimentation (presence of desquamation cells, droplets and vesicles in the ejaculate). Only those ejaculates with white color, with a volume greater than $0.1 \mathrm{ml}$ and without sedimentation were selected. Afterwards, each single ejaculate from the same male (two ejaculates per male at the same day) was pooled together. Then, we first estimated the mass motility of raw semen rating from 1 to 4 in an optical microscope (x 20 magnification), considering 1: no sperm cells with motion, 2: sperm cells moving slowly, 3: nearly all sperm cells moving with high and homogeneous motility, 4: strong waves and whirlwind appearance (based on Brun et al. [35]). Then, aliquots of semen were fixed in $2.5 \%$ glutaraldehyde to determine the semen concentration (millions of sperm cells $/ \mathrm{ml}$ ) with a Neubauer chamber and to evaluate the integrity of the acrosome in a phase-contrast microscope. To measure the percentage of live sperm and the percentage of abnormalities, the nigrosin staining technique was made for each sample. Sperm motility was assessed by Computer Assisted Semen Analysis (CASA), using the Motility module of the Sperm Class Analyzer $\left(\mathrm{SCA}^{\circledR}\right)$ version 5.2 (Microptic S.L.). To record the motility, $7 \mu \mathrm{L}$ of diluted semen in a commercial rabbit extender (Inserbo S.L., Spain) was loaded in a pre-warmed glass slide. Five to ten fields were captured and approximately 200 sperm cells were analyzed for each sample. Sperm motility variables included: total motility (MOT, \%), progressive motility (PMOT, \%), static percentage (STAT, $\%)$, curve-linear velocity (VCL, $\mu \mathrm{m} / \mathrm{s}$ ), straight-line velocity (VSL, $\mu \mathrm{m} / \mathrm{s}$ ), average path velocity (VAP, $\mu \mathrm{m} / \mathrm{s}$ ), amplitude of lateral head displacement (ALH, $\mu \mathrm{m})$, linearity (LIN, \%), straightness (STR, \%), wobble (WOB, \%) and beat cross frequency (BCF, Hz).

\subsection{Seminal plasma and blood recovery}

To separate SP from sperm cells, semen was diluted 1:2(v:v) with phosphate-buffered saline (PBS) and centrifuged $(3000 \times \mathrm{g}$ 15 min at $4{ }^{\circ} \mathrm{C}$ ) according to Garcia-Garcia et al. [10]. Supernatant was observed under a microscope to verify the absence of sperm 
cells, and then was stored at $-20^{\circ} \mathrm{C}$ until analysis.

Blood was collected from the central arterial of the ear in EDTA tubes and BP was separated by centrifugation ( $15 \mathrm{~min}, 700 \times \mathrm{g}$ at $4{ }^{\circ} \mathrm{C}$ ). Aliquots were stored at $-20^{\circ} \mathrm{C}$ until sample testing.

\subsection{Real time PCR in tissues}

Four animals of each treatment (22 and 37 weeks old) were slaughtered by cervical dislocation and reproductive tract (prostate, bulbourethral glands and caput and cauda of epididymis) was dissected; samples of $2 \mathrm{~mm}$ approximately were embedded in RNAlater $^{\circledR}$ stabilization solution (Ambion, Life Technologies, Thermo Fisher Scientific, Washington), refrigerated at $4{ }^{\circ} \mathrm{C}$ overnight and, after removing RNAlater ${ }^{\circledR}$, stored at $-80^{\circ} \mathrm{C}$ until use.

RNA extraction was carried out with Trizol reagent (Life Technologies) followed by purification using the PureLink ${ }^{\circledR}$ RNA Mini Kit (Thermo Fisher), with minor modifications of the manufacturer's instructions. Afterwards, $1 \mu \mathrm{g}$ of total RNA was treated with DNase (DNase I, RNase-free $1 \mathrm{U} / \mu \mathrm{L}$, Thermo Fisher). Reverse transcription was performed using SuperScript ${ }^{\mathrm{TM}}$ First-Strand Synthesis System for RT-PCR kit (Life Technologies) following kit's instructions.

Primers for $\beta$-NGF and TrkA genes, and GAPDH (glyceraldehyde3-phosphate dehydrogenase) as the reference housekeeping gene, were designed based on NCBI GenBank, using the OligoAnalyzer ${ }^{\mathbb{B}}$ tool (Integrated DNA Technologies) taking into account their location between exons to avoid amplification of genomic DNA (Table 1). Thereafter, $100 \mathrm{ng}$ of cDNA were relatively quantified by real-time PCR using SYBR Green (SsoAdvanced ${ }^{\mathrm{TM}}$ Universal SYBR Green Supermix, Biorad) and the following PCR cycle: $30 \mathrm{~s}$ at $95^{\circ} \mathrm{C}$, 40 cycles of $15 \mathrm{~s}$ at $95^{\circ} \mathrm{C}$ and $30 \mathrm{~s}$ at $62^{\circ} \mathrm{C}$ (ABI Prism ${ }^{\circledR} 7000$ Sequence Detection System Applied Biosystems). Non-template controls and RT negative samples were run in duplicate as negative controls. Quantification was normalized to the endogenous control GAPDH according to Herrera-Luna et al. [36], and relativized to the expression in the prostate, as reference tissue because of its high expression in rabbits [9]. The relative gene expression of the target was recorded as $\mathrm{Ct}$ values and fold changes determined using formula $2^{-\Delta \Delta C T}$, according to Livak and Schmittgen [37].

\subsection{Immunohistochemical analysis in tissues}

Samples from reproductive tract of the same 4 rabbits used for PCR analyses recovered at 22 and 37 weeks old $(n=8)$ were fixed in modified Davidson's fluid (12\% formaldehyde, 15\% ethanol, 5\% acetic glacial acid, in distilled water; all reagents were purchased from Panreac Quimica SLU, Spain) and then, embedded in paraffin and serially sectioned at $5 \mu \mathrm{m}$ of thickness. Immunohistochemistry procedure was performed as described previously [38] with minor modifications. Deparaffination, rehydration and blocking of endogenous peroxidase with $3 \% \mathrm{H}_{2} \mathrm{O}_{2}$ for $\beta$-NGF and $0.3 \%$ for TrkA for $30 \mathrm{~min}$ at room temperature were first performed. After, heat induced epitope retrieval in $10 \mathrm{mM}$ sodium citrate buffer $(\mathrm{pH} \mathrm{6})$ and incubation with normal horse serum (for $\beta$-NGF, Vector
Laboratories) or normal goat serum (for TrkA, Vector Laboratories) dilution 1:10 in PBS was done. Samples were incubated overnight at $4{ }^{\circ} \mathrm{C}$ in a moist chamber with goat anti- $\beta$-NGF antibody $(1: 100$, N8773, Sigma Aldrich) or mouse monoclonal anti-TrkA antibody (1:200, ab86474, Abcam), respectively. For negative control samples, PBS was used instead of the primary antibody. After incubation, secondary antibodies diluted 1:200 were added for $30 \mathrm{~min}$ at room temperature [biotinylated horse anti-goat IgG for $\beta$-NGF (BA9500, Vector Laboratories) or biotinylated goat anti-mouse IgG for TrkA (BA9200, Vector Laboratories)]. Afterwards, slides were incubated with the avidin-biotin complex ( $A B C$ Vector Elite kit, Vector Laboratories) at room temperature for $30 \mathrm{~min}$, and then incubated with peroxidase chromogen (Vector Nova RED substrate Kit for Peroxidase, Vector Laboratories) and counterstained with hematoxylin. Ten representative images of each tissue of every male were taken using a light microscope (Leica F550) equipped with phase contrast optics and a DCF400 camera. The intensity of the signal was considered as mild + , moderated ++ or strong +++ . Rabbit pituitary and hypothalamus were used as positive control tissues. All samples were evaluated by the same blinded observer.

\subsection{Western blot in seminal plasma}

$\beta$-NGF protein in SP from 6 males in the two ages studied was analyzed by western blot according to Garcia-Garcia et al. [10] with minor modifications. $\beta$-actin protein was used to normalize samples. SP was denatured in loading buffer at $95^{\circ} \mathrm{C}$ and $50 \mu \mathrm{g}$ of total protein for each sample were separated on 12\% SDS-PAGE gels at $90 \mathrm{~V}$ for $2 \mathrm{~h}$. Proteins were transferred onto nitrocellulose membranes (Amersham ${ }^{\mathrm{TM}}$ Hybond $^{\mathrm{TM}}$ ECL, GE Healthcare) (160 mA for $80 \mathrm{~min}$ ), blocked during $1 \mathrm{~h}$ in Odyssey ${ }^{\circledR}$ Blocking buffer (LI-COR Biosciences) and then incubated overnight at $4{ }^{\circ} \mathrm{C}$ with goat anti- $\beta$ NGF antibody $(0.1 \mu \mathrm{g} / \mathrm{mL}$, N8773, Sigma-Aldrich) and mouse monoclonal anti- $\beta$-actin antibody $(1 \mu \mathrm{g} / \mathrm{mL}, \mathrm{A} 2228$, Sigma Aldrich) in blocking buffer with $0.1 \%$ Tween 20 . After several washes, membranes were incubated at room temperature for $1 \mathrm{~h}$ with the secondary antibodies [IRDye ${ }^{\circledR} 800 \mathrm{CW}$ donkey anti-goat $\operatorname{IgG}(\mathrm{H}+\mathrm{L})$ for $\beta$-NGF and IRDye ${ }^{\circledR} 680 \mathrm{CW}$ goat anti-mouse $\operatorname{IgG}(\mathrm{H}+\mathrm{L})$ for $\beta$ actin, LI-COR Biosciences] and scanned with an Odyssey fluorescence scanner (LI-COR Bioscience). The densitometry of $13 \mathrm{kDa}$ bands ( $\beta$-NGF) and $42 \mathrm{kDa}$ bands ( $\beta$-actin) of each male in the two ages studied were measured with Image Studio Lite 5.2 (LI-COR Bioscience). We obtained the ratio of $\beta$-NGF to $\beta$-actin.

\subsection{Enzimoimmunoassay in seminal plasma and blood plasma}

Concentration of $\beta$-NGF and testosterone was assessed by enzyme-linked immunosorbent assay (ELISA). Hence, in BP and SP, $\beta$-NGF was analyzed following the recommendations of the rabbit $\beta$-NGF ELISA kit (abx259154, Abbexa). SP samples were diluted 1:2 (v:v) in PBS (final dilution of SP 1:4) whereas BP was undiluted. Testosterone BP was measured with a commercial kit from Demeditec (DE1559) following manufacturer's instructions. For

Table 1

Primers for $\beta$-NGF, TrkA and GADPH for real time PCR quantification.

\begin{tabular}{|c|c|c|c|}
\hline Gene & $\begin{array}{l}\text { Nucleotide sequence } \\
5^{\prime}-3^{\prime}\end{array}$ & Size of PCR product (bp) & NCBI Reference sequence \\
\hline$\beta-N G F$ & $\begin{array}{l}\text { F: GCCACGCTGAGGTGCATAG } \\
\text { R: TGCATGTGGTTCCGCCTGTAT }\end{array}$ & 89 & XM_017345952.1 \\
\hline TrkA & $\begin{array}{l}\text { F: CGGCTGAGTCACCTGAATCTC } \\
\text { R: GAGTTCCCCGACAGGACC }\end{array}$ & 174 & XM_008264290.2 \\
\hline GADPH & $\begin{array}{l}\text { F: GTCGGAGTGAACGGATTTGG } \\
\text { R: AAAGCAGCCCTGGTGACCA }\end{array}$ & 53 & NM_001082253.1 \\
\hline
\end{tabular}


both kits, the absorbance at $450 \mathrm{~nm}$ was determined in a microplate reader (Bench Marck Plus Microplate Spectrophotometer System, Bio-Rad). The intra-assay variation of the test for $\beta$-NGF was $C V<8 \%$, and inter-assay, $\mathrm{CV}<10 \%$.The intra- and inter-assay coefficients of variation were $3.28 \%$ and $4.73 \%$ for the lowest testosterone concentration and $4.16 \%$ and $9.94 \%$ for the highest testosterone concentration, respectively. Standard absorbance was used to generate a logistic four-parameter sigmoidal standard curve with Sigma Plot Software. Then, the concentration of the samples was calculated by extrapolating the absorbance in the equation of the sigmoidal curve.

\subsection{Statistical analysis}

The variables were analyzed using the SAS software version 9.0 (Statistical Analysis System Institute Inc). The relative gene expression of the targets $\beta$-NGF and TrkA was analyzed by two-way ANOVA (PROC GLM) with tissues (prostate, bulbourethral glands, caput of epididymis and cauda of epididymis) and age (22 and 37 weeks old) as fixed effects, including also in the model the interaction between both fixed effects. For seminal parameters, we used a one-way ANOVA with repeated measures (PROC MIXED) and age as fixed effect. $\beta$-NGF concentration in BP and SP, testosterone concentration in BP and the ratio of $\beta-N G F / \beta$-actin in SP were analyzed also by one-way ANOVA with repeated measures and age as the fixed effect. All data are presented as LSMEANS \pm SEM and Fisher test was used as a post-hoc test to compare means, with differences considered significant when $\mathrm{P}<0.05$. We also determined correlation coefficients by the Pearson test (PROC CORR) to describe the relationship between SP and BP $\beta$-NGF levels and SP/ $\mathrm{BP} \beta-\mathrm{NGF}$ and $\mathrm{BP}$ testosterone concentrations.

\section{Results}

Expression of $\beta$-NGF and TrkA mRNA in prostate, bulbourethral glands and epididymis by RT-PCR is shown in Fig. 1. Gene

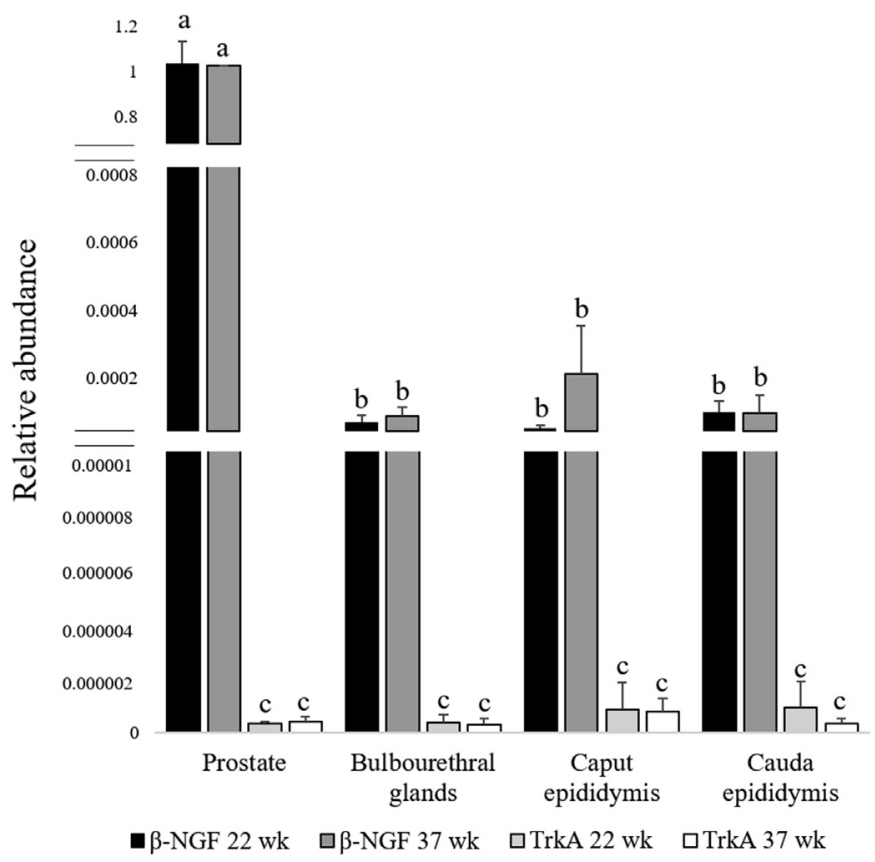

Fig. 1. Gene expression in male reproductive tissues of $\beta$-NGF and TrkA. Different letters indicate significant differences $(p<0.05)$. Note the change of scale in $\beta$-NGF expression. expression of $\beta$-NGF was greater $(\mathrm{P}<0.05)$ in prostate than in bulbourethral glands and epididymis; its expression for all sex organ tissues was higher than for TrkA receptor $(P<0.05)$. There was no effect of age of rabbits $(\mathrm{p}<0.05)$ on the abundance of $\beta$-NGF and TrkA among tissues.

In the immunolocalization study, $\beta$-NGF was mainly found in the prostate in both ages (Fig. 2). The cytoplasm of epithelial cells and the lumen were strongly stained $(+++)$. However, it was differentially immunolocalized (Fig. 2A and D); whereas the staining was higher in the apical zone of prostate epithelial cells at 22 weeks old, the protein was uniformly distributed in the entire cytoplasm at 37 weeks old. Furthermore, the interstitial tissue in older males had a moderated staining $(++)$ in contrast to younger males, which did not show any signal in that tissue. Bulbourethral glands did not present any cytoplasmic or nuclear staining in the epithelial cells. Signal was mild $(+)$ in interstitial tissue in young males and moderated $(++)$ at week 37 (Fig. 2F and J). No signal was found in any compartment of caput and cauda of the epididymis (Fig. 2K, O, P and S).

For the high-affinity receptor, TrkA, the expression pattern was similar between younger and older males for prostate and bulbourethral glands (Fig. 3). Membrane of prostate epithelial cells showed strong signal $(+++)$. Interstitial tissue was mild stained $(+)$ (Fig. 3A and D). In bulbourethral glands, strong staining $(+++)$ appeared in epithelial cells in both ages, whereas interstitial tissue showed mild signal $(+$ ) (Fig. 3F and J). Staining in caput (Fig. 4K and O) and cauda (Fig. 3P and S) of epididymis was strong $(+++)$ in both epithelial cells and interstitial tissue, although some differential immunolocalization was appreciated. In 22 week-old males, the signal for TrkA in epithelial cell and stereocilia were stronger $(++)$ than in older males $(+)$.

Negative control tissue samples showed no signal and positive control tissues (hypothalamus and hypophysis) were stained by $\beta$ NGF and TrkA (Supplementary Fig. 1).

Results of semen analysis are shown in Table 2. Sperm concentration, the percentage of alive sperm and mass and progressive motility assessed with CASA were higher in 37 than 22-week old rabbits $(P<0.05)$. The rest of sperm parameters were similar for both ages.

Western blot confirmed the presence of $\beta$-NGF protein in male $\mathrm{SP}$ as sexual maturity is being acquired in rabbit. The relative quantification showed similar levels of $\beta$-NGF between the two sexual ages studied (Fig. 4).

Analysis of blood and seminal plasma showed that $\beta$-NGF concentration was higher in SP than in BP, but there were no differences between younger and older males in any of the plasmas (Table 2). There was a significantly higher concentration of testosterone in BP at week 22 compared to week $37(\mathrm{P}<0.05)$. There was no correlation between $\beta$-NGF levels in SP and BP $(r=-0.014$, $P=0.956)$, or SP $\beta-N G F$ and BP testosterone levels $(r=-0.356$, $\mathrm{P}=0.147)$. Correlation between $\mathrm{BP} \beta-\mathrm{NGF}$ and testosterone concentrations was not significant either $(r=0.1650, P=0.513)$.

\section{Discussion}

The present study is the first to report the gene expression and distribution of $\beta-\mathrm{NGF}$ and TrkA in prostate, bulbourethral glands, epididymis and SP during the development of the sexual maturity in rabbits, showing high abundance in prostate during the sexual development and the differential distribution of $\beta$-NGF/TrkA system in some organs according to the sexual stage. In addition, seminal parameters and testosterone concentration changed according to the period of sexual maturity, whereas the $\beta$-NGF concentration in SP and in BP was unaffected.

The highest mRNA expression in prostate besides the other male 


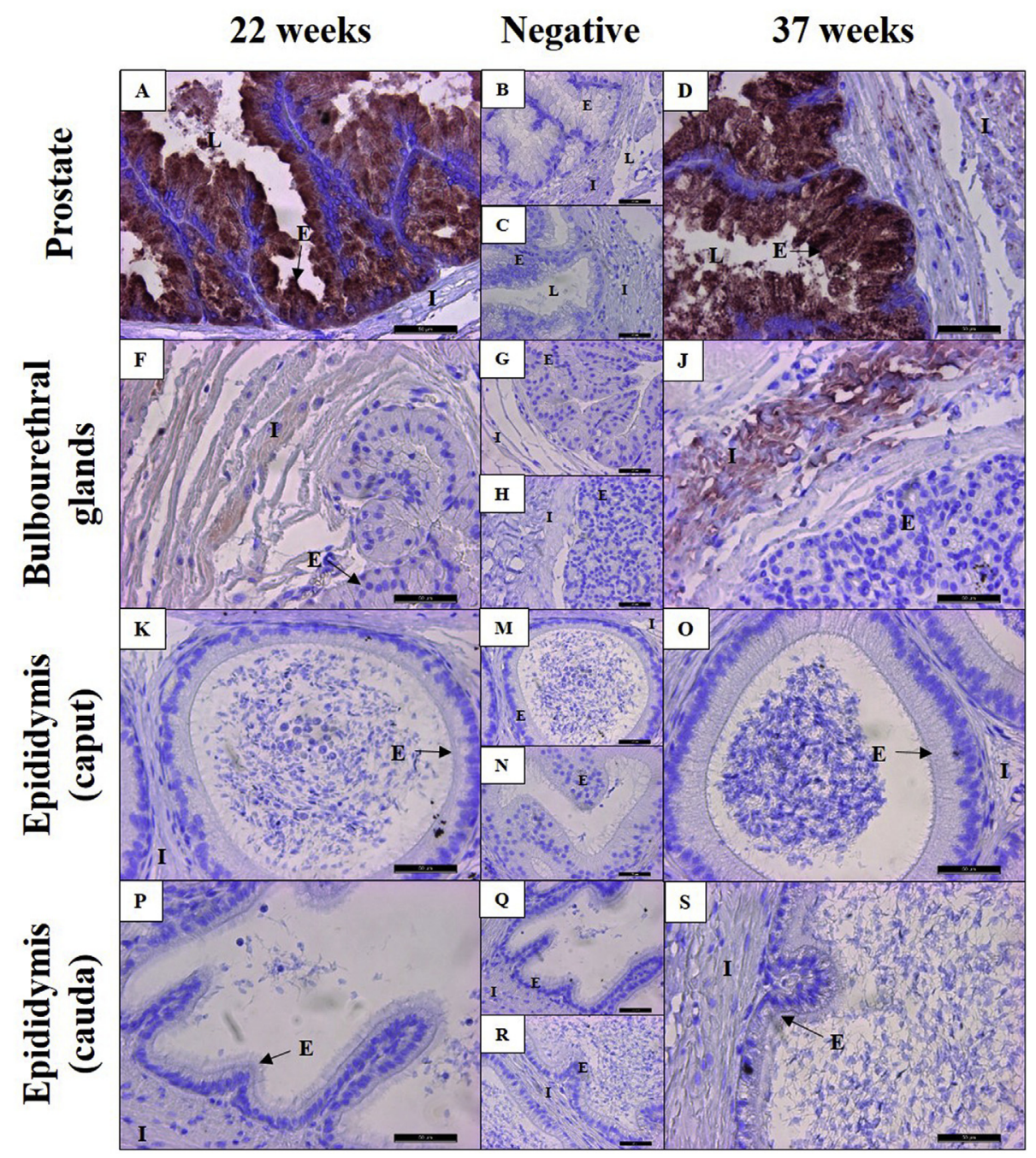

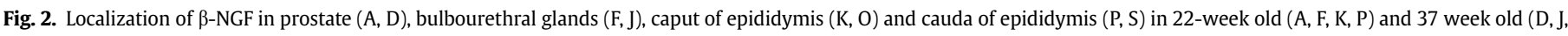

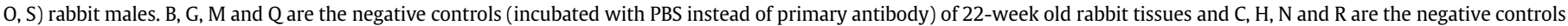
of 37-week old rabbits. Abbreviations: E, epithelial cells; I, interstitial tissue; L, lumen. Scale bar is $50 \mu \mathrm{m}$.

reproductive tissues together with its widespread distribution of $\beta$ NGF in the secretory epithelial cells and lumen confirmed the contribution of this tissue to $\beta$-NGF production (synthesis, store and secretion) during the sexual maturation period in rabbit. However, bulbourethral glands and epididymis also expressed $\beta$ NGF mRNA suggesting its production in these cells. The highest gene expression of $\beta$-NGF in adult male prostate has been described in other species (human [4,39,40], guinea pig [3,41], mouse [41], rat $[5,7,41]$, bull [2], llamas and alpacas [42]) and also in rabbit [2,9,10]. Wang and collaborators [43] found a similar $\beta$-NGF expression in testes between 12 and 24-month old alpacas, which corresponds to the sexual maturity period in this species, but little is known on differences on $\beta$-NGF expression during the process of sexual maturity; the studies have been mainly focused in the prenatal period where the neurotrophin has been localized in testis and epididymis [16,17,43-45].

In the present study, some differences in the immunolocalization of $\beta$-NGF in prostate were found among the two developmental stages. The protein was localized with higher intensity in the apical zone of epithelial cells in younger individuals, whereas in older males the intensity was the same all over the cytoplasm. This could indicate that there may be a higher production of $\beta$-NGF in younger males, but $\beta$-NGF would not be secreted in the ejaculate as, according to our results, the $\beta$-NGF concentration in SP did not change. Therefore, $\beta$-NGF could be stored in the male tract and act by autocrine, paracrine or yuxtracrine mechanisms [7] and may contribute to the improvement of the seminal parameters such as concentration or motility, which are better in older males in the current study. In contrast to other species, we did not find $\beta$-NGF staining in the prostate interstitial tissue of 22 -week rabbits, as also happens in humans [39]; therefore, cells in the interstitial tissue of the rabbit prostate does not seem to be involved in neurotrophin provision to epithelial cells of prostate in early ages.

In contrast to the wide localization of $\beta$-NGF in the epithelial cells of the prostate, staining for this protein was absent in the bulbourethral glands and in the epithelial cells of the caput and cauda of the epididymis. This is in agreement with Harper and Thoenen [2], who determined very low quantity of $\beta$-NGF in bulbourethral glands. This result leads us to consider that these tissues are not the main producers of $\beta$-NGF. However, the mild staining found in the interstitial tissue of bulbourethral glands together with the strong intensity of TrkA in its epithelial cells denote that this tissue could respond to $\beta$-NGF as suggested by Squillacioti et al. [7] during sexual development. 


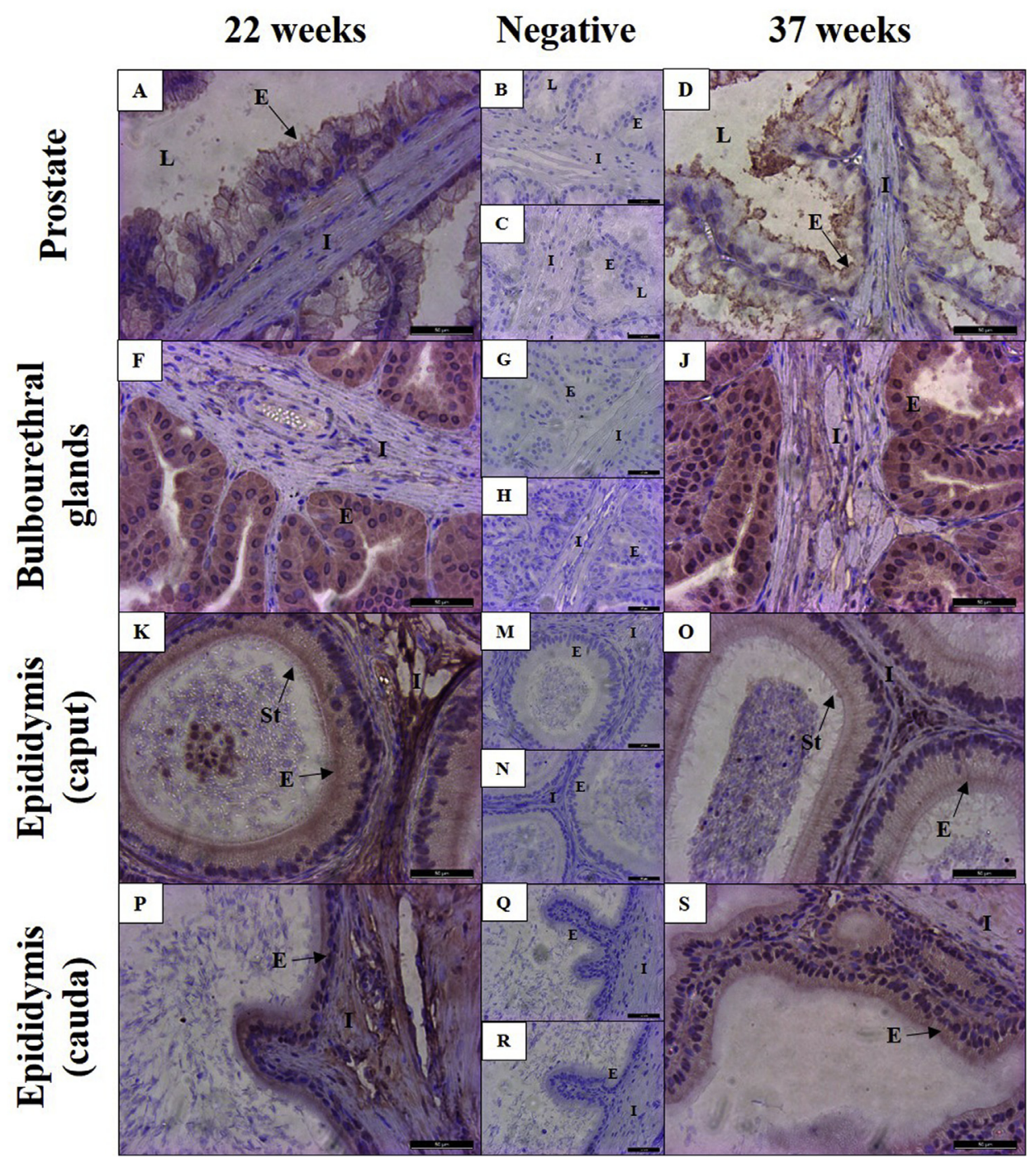

Fig. 3. Localization of TrkA in prostate (A, D), bulbourethral glands (F, J), caput of epididymis (K, O) and cauda of epididymis (P, S) in 22 -week old (A, F, K, P) and 37 week old (D, J, O, S) rabbit males. B, G, M and Q are the negative controls (incubated with PBS instead of primary antibody) of 22-week old rabbit tissues and C, H, N and R are the negative controls (incubated with PBS instead of primary antibody) of 37-week old rabbits. Abbreviations: E, epithelial cells; I, interstitial tissue; L, lumen; St, stereocilia. Scale bar is $50 \mu$ m.

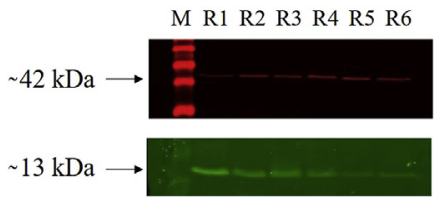

22 weeks old
R1 R2 M R3 R4 R5 R6

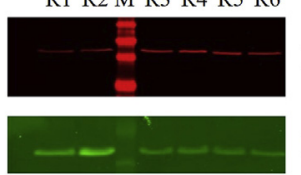

37 weeks old
Fig. 4. Western blot of $\beta$-NGF vs. $\beta$-actin in SP of rabbits at 22 and 37 weeks old. Lane M (Molecular Weight Markers): 10-250 kDa; R1-6: SP of rabbit 1-6.

Gene expression of TrkA was low in sex organs but it was immunolocalized in all the tissues studied. A remarkable finding was the presence of this receptor in the stereocilia of the caput of epididymis. The localization of $\beta$-NGF [42] and the other $\beta$-NGF cognate receptor p75 [33] in these structures has been also reported. The presence of a greater proportion of TrkA in stereocilia in younger individuals could be associated with the function of epididymis of achieving a proper sperm concentration, shown in older individuals. Another hypothesis about the localization of TrkA in caput of epididymis, is that it could be relatively implicated in giving the sperm the proper motility, as seen in motility parameters measured by CASA (PMOT), since the change of the motility pattern from caput to cauda of epididymis depends on some factors produced by the epididymis epithelium [15]. Also, it could indicate that $\beta$-NGF is partially implicated in the sperm maturation and migration when rabbit males reach the sexual maturity, since the epididymis is known to play a major role in maturation of spermatozoids [46].

Sperm motility and viability in older males were improved. However, $\beta$-NGF levels in SP among ages were similar. These results are in contrast with Parthipan et al. [30], who detected higher concentrations of $\beta$-NGF in bulls showing better semen characteristics. Moreover, reports in humans have found that the $\beta-N G F / T r k A$ system exerts effects on semen parameters [47,48]. $\beta$-NGF levels observed in the SP were similar to those reported in rabbits $[9,49]$ but $\beta$-NGF concentration in BP was higher than those described by Maranesi et al. [9]. Differences among studies may be explained in terms of different kits and laboratory techniques used. In the current study, both $\beta$-NGF concentrations in SP and BP were unchanged whereas testosterone levels decreased from 22 to 37 weeks. BP testosterone levels gradually increase from puberty to maturity but also present peaks during this period [50]; this 
Table 2

Seminal characteristics and $\beta$-NGF levels in blood plasma and seminal plasma (pg/mL) and testosterone in blood plasma (pg/mL) at week 22 and 37 in rabbit males $(n=6)$. VCL: Curvilinear velocity; VSL: Straight-line velocity; VAP: Average path velocity; ALH: Amplitude of lateral head displacement; LIN: Linearity; STR: Straightness; WOB: Wobble; BCF: Beat cross frequency. Data are presented as least square means \pm SEM. Different letters in the same row indicate significant differences $(\mathrm{P}<0.05)$.

\begin{tabular}{|c|c|c|c|}
\hline \multirow[t]{2}{*}{ Seminal variable } & \multicolumn{2}{|l|}{ Age of male rabbits } & \multirow[t]{2}{*}{ P-value } \\
\hline & 22 weeks & 37 weeks & \\
\hline Volume $(\mathrm{mL})$ & $1.12 \pm 0.12$ & $0.78 \pm 0.14$ & 0.072 \\
\hline \multicolumn{4}{|l|}{ Spermatic variables } \\
\hline Mass motility $(1-4)$ & $2.98 \pm 0.25^{\mathrm{a}}$ & $3.70 \pm 0.27^{b}$ & 0.031 \\
\hline Total motility, MOT (\%) & $68.61 \pm 1.89$ & $78.33 \pm 2.34$ & 0.067 \\
\hline Progressive motility, PMOT (\%) & $24.35 \pm 2.10^{\mathrm{a}}$ & $39.33 \pm 2.45^{\mathrm{b}}$ & 0.012 \\
\hline Sperm Concentration $\left(\times 10^{6} \mathrm{~mL}^{-1}\right)$ & $131.18 \pm 18.25^{\mathrm{a}}$ & $266.27 \pm 23.13^{b}$ & 0.012 \\
\hline Live sperm (\%) & $53.29 \pm 5.89^{\mathrm{a}}$ & $64.04 \pm 6.13^{\mathrm{b}}$ & 0.040 \\
\hline Abnormalities (\%) & $28.40 \pm 4.73$ & $31.75 \pm 4.82$ & 0.168 \\
\hline Acrosome integrity (\%) & $67.71 \pm 5.67$ & $67.81 \pm 5.88$ & 0.974 \\
\hline \multicolumn{4}{|l|}{ Sperm Kinematics } \\
\hline Static sperm (\%) & $32.39 \pm 2.17$ & $22.15 \pm 2.59$ & 0.063 \\
\hline $\mathrm{VCL}(\mu \mathrm{m} / \mathrm{s})$ & $98.50 \pm 5.00$ & $95.37 \pm 5.67$ & 0.669 \\
\hline $\operatorname{VSL}(\mu \mathrm{m} / \mathrm{s})$ & $41.69 \pm 3.10$ & $49.16 \pm 3.42$ & 0.095 \\
\hline $\operatorname{VAP}(\mu \mathrm{m} / \mathrm{s})$ & $65.78 \pm 4.36$ & $66.95 \pm 4.24$ & 0.806 \\
\hline ALH $(\mu \mathrm{m})$ & $2.63 \pm 0.09$ & $2.40 \pm 0.11$ & 0.214 \\
\hline $\operatorname{LIN}(\%)$ & $43.83 \pm 3.44$ & $52.71 \pm 2.87$ & 0.100 \\
\hline STR (\%) & $63.95 \pm 3.14$ & $71.68 \pm 2.99$ & 0.109 \\
\hline WOB (\%) & $69.58 \pm 2.50$ & $72.26 \pm 2.34$ & 0.458 \\
\hline $\mathrm{BCF}(\mathrm{Hz})$ & $9.93 \pm 0.30$ & $10.37 \pm 0.35$ & 0.417 \\
\hline \multicolumn{4}{|l|}{$\beta$-NGF concentration $(\mathrm{pg} / \mathrm{mL}$ ) } \\
\hline Seminal plasma & $1378.6 \pm 375.0$ & $1240.3 \pm 270.4$ & 0.771 \\
\hline Blood plasma & $658.9 \pm 30.2$ & $746.6 \pm 125.7$ & 0.513 \\
\hline \multicolumn{4}{|l|}{ Testosterone concentration $(\mathrm{pg} / \mathrm{mL})$} \\
\hline Blood plasma & $4427.9 \pm 1432.1^{\mathrm{a}}$ & $692.1 \pm 201.1^{\mathrm{b}}$ & 0.022 \\
\hline
\end{tabular}

variance in testosterone concentration may be associated with a role in the development of reproductive accessory organs. However, based on our findings, $\beta$-NGF concentration seems to be testosterone independent as occurs in guinea pigs [41], where $\beta$ NGF is not directly regulated by androgens.

In conclusion, $\beta$-NGF and its high-affinity receptor, TrkA, are present in prostate, bulbourethral glands and epididymis of rabbit male tract during sexual maturation. Prostate seems to be the tissue with the highest production and secretion of $\beta$-NGF, and its expression and concentration in SP and BP remain constant throughout the maturation process, independently of testosterone $\mathrm{BP}$ concentration. $\beta$-NGF may be involved in rabbit male reproduction by endocrine/autocrine pathway, interacting with TrkA receptor which could improve seminal parameters, such as the concentration or sperm motility.

\section{Author's contributions}

RMGG, PL, PGR, MAA and ASR conceived the study; RMGG, ASR, MAA and JMB designed the experiments or part of them. ASR, MAA, PT, PGR and RMGG participated in acquisition and analysis of the data. All authors contributed to revisions of the manuscript.

\section{Acknowledgements}

This work was supported by the Ministry of Economy and Competitiveness of Spain [grant AGL2015-65572-C2] and Predoctoral Contract UCM-Santander of ASR. We thank the Histology Facilities at CNB-CSIC for the histological preparation of biological samples, P Abad for helping in western blot and ELISA techniques, $\mathrm{M}$ Rodriguez and B Velasco for helping in the farm handling.

\section{Appendix A. Supplementary data}

Supplementary data to this article can be found online at https://doi.org/10.1016/j.theriogenology.2018.12.013.

\section{References}

[1] Cohen S, Levi-Montalcini R, Hamburger V. A nerve growth-stimulating factor isolated from Sarcom as 37 and 180. Proc Natl Acad Sci U S A 1954;40:1014-8.

[2] Harper GP, Thoenen H. The distribution of nerve growth factor in the male sex organs of mammals. J Neurochem 1980;34:893-903.

[3] Shikata H, Utsumi N, Hiramatsu M, Minami N, Nemoto N, Shikata T. Immunohistochemical localization of nerve growth factor and epidermal growth factor in Guinea pig prostate gland. Histochemistry 1984;80:411-3.

[4] Djakiew D. Role of nerve growth factor-like protein in the paracrine regulation of prostate growth. J Androl 1992;13:476-87.

[5] Li C, Watanabe G, Weng Q Jin W, Furuta C, Suzuki AK, et al. Expression of nerve growth factor (NGF), and its receptors TrkA and p75 in the reproductive organs of the adult male rats. Zool Sci 2005;22:933-7.

[6] Jin W, Arai KY, Shimizu K, Kojima C, Itoh M, Watanabe G, et al. Cellular localization of NGF and its receptors trkA and p75LNGFR in male reproductive organs of the Japanese monkey, Macaca fuscata fuscata. Endocrine 2006;29: 155-60.

[7] Squillacioti C, De Luca A, Paino S, Langella E, Mirabella N. Effects of castration on the expression of the NGF and TrkA in the vas deferens and accessory male genital glands of the rat. EJH 2009;53:e29.

[8] Arrighi N, Bodei S, Zani D, Simeone C, Cunico SC, Missale C, et al. Nerve growth factor signaling in prostate health and disease. Growth Factors 2010;28: $191-201$.

[9] Maranesi M, Zerani M, Leonardi L, Pistilli A, Arruda-Alencar J, Stabile A, et al, Gene expression and localization of NGF and its cognate receptors NTRK1 and NGFR in the sex organs of male rabbits. Reprod Domest Anim 2015;50: 918-25.

[10] Garcia-Garcia RM, Masdeu MM, Sanchez-Rodriguez A, Millan P, AriasAlvarez M, Sakr OG, et al. $\beta$-nerve growth factor identification in male rabbit genital tract and seminal plasma and its role in ovulation induction in rabbit does. Ital J Anim Sci 2018;17(2):442-53.

[11] Dissen GA, Hirshfield AN, Malamed S, Ojeda SR. Expression of neurotrophins and their receptors in the mammalian ovary is developmentally regulated: changes at the time of folliculogenesis. Endocrinology 1995;136:4681-92.

[12] Levanti MB, Germana A, Abbate F, Montalbano G, Vega JA, Germana G. TrkA and p75NTR in the ovary of adult cow and pig. J Anat 2005;207:93-6.

[13] Jana B, Koszykowska M, Czarzasta J. Expression of nerve growth factor and its receptors, TrkA and p75, in porcine ovaries. J Reprod Dev 2011;57:468-74.

[14] Maranesi M, Parillo F, Leonardi L, Rebollar PG, Alonso B, Petrucci L, et al. Expression of nerve growth factor and its receptors in the uterus of rabbits: functional involvement in prostaglandin synthesis. Domest Anim Endocrinol 2016;56:20-8.

[15] Ayer-LeLievre C, Olson L, Ebendal T, Hallbook F, Persson H. Nerve growth 
factor mRNA and protein in the testis and epididymis of mouse and rat. Proc Natl Acad Sci U S A 1988;85:2628-32.

[16] Cupp AS, Kim GH, Skinner MK. Expression and action of neurotropin-3 and nerve growth factor in embryonic and early postnatal rat testis development. Biol Reprod 2000;63:1617-28.

[17] Muller D, Davidoff MS, Bargheer O, Paust HJ, Pusch W, Koeva Y, et al. The expression of neurotrophins and their receptors in the prenatal and adult human testis: evidence for functions in Leydig cells. Histochem Cell Biol 2006:126:199-211.

[18] Perrard MH, Vigier M, Damestoy A, Chapat C, Silandre D, Rudkin BB, et al. beta-Nerve growth factor participates in an auto/paracrine pathway of regulation of the meiotic differentiation of rat spermatocytes. J Cell Physiol 2007; 210:51-62.

[19] Li C, Zhou X. The potential roles of neurotrophins in male reproduction. Reproduction 2013;145:R89-95.

[20] Persson H, Ayer-Le Lievre C, Soder O, Villar MJ, Metsis M, Olson L, et al. Expression of beta-nerve growth factor receptor mRNA in Sertoli cells downregulated by testosterone. Science 1990;247:704-7.

[21] Lonnerberg P, Soder O, Parvinen M, Ritzen EM, Persson H. Beta-nerve growth factor influences the expression of androgen-binding protein messenger ribonucleic acid in the rat testis. Biol Reprod 1992;47:381-8.

[22] Chen BX, Yuen ZX, Pan GW. Semen-induced ovulation in the bactrian camel (Camelus bactrianus). J Reprod Fertil 1985;74:335-9.

[23] Adams GP, Ratto MH, Huanca W, Singh J. Ovulation-inducing factor in the seminal plasma of alpacas and llamas. Biol Reprod 2005;73:452-7.

[24] Silva M, Nino A, Guerra M, Letelier C, Valderrama XP, Adams GP, et al. Is an ovulation-inducing factor (OIF) present in the seminal plasma of rabbits? Anim Reprod Sci 2011;127:213-21.

[25] Adams GP, Ratto MH, Silva ME, Carrasco RA. Ovulation-inducing factor (OIF/ NGF) in seminal plasma: a review and update. Reprod Domest Anim 2016;51Suppl 2:4-17.

[26] Casares-Crespo L, Talavan AM, Viudes-de-Castro MP. Can the genetic origin affect rabbit seminal plasma protein profile along the year? Reprod Domes Anim 2016;51:294-300.

[27] Gonzalez-Cadavid V, Martins JA, Moreno FB, Andrade TS, Santos AC, MonteiroMoreira AC, et al. Seminal plasma proteins of adult boars and correlations with sperm parameters. Theriogenology 2014:82:697-707.

[28] Rodriguez-Martinez H, Kvist U, Ernerudh J, Sanz L, Calvete JJ. Seminal plasma proteins: what role do they play? Am J Reprod Immunol 2011;66(Suppl 1): $11-22$.

[29] Simmons LW, Fitzpatrick JL. Sperm wars and the evolution of male fertility. Reproduction 2012;144:519-34.

[30] Parthipan S, Selvaraju S, Somashekar L, Arangasamy A, Sivaram M, Ravindra JP. Spermatozoal transcripts expression levels are predictive of semen quality and conception rate in bulls (Bos taurus). Theriogenology 2017;98:41-9.

[31] Masdeu M, Garcia-Garcia RM, Millan P, Revuelta L, Sakr OG, Blanco PG, Cortegano D, Lorenzo PL, Rebollar PG. Effect of rabbit seminal plasma in ovulating response. Reprod Fertil Dev 2012;25(1):243.

[32] Maranesi M, Petrucci L, Leonardi L, Piro F, Rebollar PG, Millan P, et al. New insights on a NGF-mediated pathway to induce ovulation in rabbits (Oryctolagus cuniculus). Biol Reprod 2018;98:634-43.

[33] Sanchez-Rodriguez A, Arias-Alvarez M, Rebollar PG, Bautista JM, Lorenzo PL, Garcia-Garcia RM. Gene expression and immunolocalization of low-affinity neurotrophin receptor (p75) in rabbit male reproductive tract during sexual maturation. Reprod Domest Anim 2018;53(Suppl.2):62-5.
[34] Boletín Oficial del Estado. Real Decreto 53/2013 de 1 de febrero, por el que se establecen las normas básicas aplicables para la protección de los animales utilizados en experimentación y otros fines científicos, incluyendo la docencia. BOE 34(I): 11370-11421.

[35] Brun JM, Theau-Clément M, Bolet G. The relationship between rabbit semen characteristics and reproductive performance after artificial insemination. Anim Reprod Sci 2002;70:139-49.

[36] Herrera-Luna CV, Budik S, Aurich C. Gene expression of ACTH, glucocorticoid receptors, 11betaHSD enzymes, LH-, FSH-, GH receptors and aromatase in equine epididymal and testicular tissue. Reprod Domest Anim 2012;47: $928-35$.

[37] Livak KJ, Schmittgen TD. Analysis of relative gene expression data using realtime quantitative PCR and the 2(-Delta DeltaC(T)) method. Methods 2001;25: 402-8.

[38] Arias-Alvarez M, Garcia-Garcia RM, Torres-Rovira L, Gonzalez-Bulnes A, Rebollar PG, Lorenzo PL. Influence of leptin on in vitro maturation and steroidogenic secretion of cumulus-oocyte complexes through JAK2/STAT3 and MEK 1/2 pathways in the rabbit model. Reproduction 2010;139:523-32.

[39] Satoh F, Mimata H, Nomura T, Fujita Y, Shin T, Sakamoto S, et al. Autocrine expression of neurotrophins and their receptors in prostate cancer. Int J Urol 2001;8:S28-34.

[40] Guate JL, Fernandez N, Lanzas JM, Escaf S, Vega JA. Expression of p75(LNGFR) and Trk neurotrophin receptors in normal and neoplastic human prostate. BJU Int 1999;84:495-502.

[41] MacGrogan D, Despres G, Romand R, Dicou E. Expression of the beta-nerve growth factor gene in male sex organs of the mouse, rat, and Guinea pig. J Neurosci Res 1991;28:567-73.

[42] Bogle OA, Carrasco RA, Ratto MH, Singh J, Adams GP. Source and localization of ovulation-inducing factor/nerve growth factor in male reproductive tissues among mammalian species. Biol Reprod 2018. https://doi.org/10.1093/biolre/ ioy 149 .

[43] Wang H, Dong Y, Chen W, Hei J, Dong C. Expression and localization of nerve growth factor (NGF) in the testis of alpaca (llama pacos). Folia Histochem Cytobiol 2011;49:55-61.

[44] Djakiew D, Pflug B, Dionne C, Onoda M. Postnatal expression of nerve growth factor receptors in the rat testis. Biol Reprod 1994;51:214-21.

[45] Russo MA, Giustizieri ML, Favale A, Fantini MC, Campagnolo L, Konda D, et al. Spatiotemporal patterns of expression of neurotrophins and neurotrophin receptors in mice suggest functional roles in testicular and epididymal morphogenesis. Biol Reprod 1999;61:1123-32.

[46] Sullivan R, Mieusset R. The human epididymis: its function in sperm maturation. Hum Reprod Update 2016;22:574-87.

[47] Li C, Zheng L, Wang C, Zhou X. Absence of nerve growth factor and comparison of tyrosine kinase receptor A levels in mature spermatozoa from oligoasthenozoospermic, asthenozoospermic and fertile men. Clin Chim Acta 2010;411:1482-6.

[48] Lin K, Ding XF, Shi CG, Zeng D, QuZong S, Liu SH, et al. Nerve growth factor promotes human sperm motility in vitro by increasing the movement distance and the number of A grade spermatozoa. Andrologia 2015;47:1041-6.

[49] Casares-Crespo L, Fernandez-Serrano P, Vicente JS, Moce E, Castellini C, Stabile AM, et al. Insemination extender supplementation with bestatin and EDTA has no effect on rabbit reproductive performance. Theriogenology 2018;105:61-5.

[50] Berger M, Chazaud J, Jean-Faucher C, de Turckheim M, Veyssiere G, Jean C. Developmental patterns of plasma and testicular testosterone in rabbits from birth to 90 days of age. Biol Reprod 1976;15:561-4. 